\title{
„GORSZE JEST WROGIEM ZŁEGO”, CZYLI „NAPRAWIANIE” BŁĘDÓW LEGISLACYJNYCH NA PRZYKŁADZIE REGULACJI DOTYCZĄCEJ PODATKU OD WYJŚCIA
}

Streszczenie. Celem artykułu jest ocena wprowadzonego do polskiego systemu prawnego w 2019 r. podatku od wyjścia od osób fizycznych, $\mathrm{z}$ uwzględnieniem przede wszystkim modelu jego płatności. To właśnie ten element konstrukcji exit tax ma najistotniejsze znaczenie dla ustalenia zgodności całej analizowanej regulacji z prawem Unii Europejskiej oraz zasadami i wartościami konstytucyjnymi. W tym zakresie na szczególną uwagę zasługuje Rozporządzenie Ministra Finansów z dnia 27 czerwca 2019 r. przedłużające termin płatności podatku od wyjścia w przypadku osób fizycznych, stanowiące przykład wyjątkowo nieudanej i prawnie wadliwej próby „naprawiania” wcześniejszych błędów ustawodawcy.

Słowa kluczowe: podatek od wyjścia, niezrealizowane zyski kapitałowe, ulgi w zapłacie podatku, odroczenie płatności podatku

\section{WPROWADZENIE}

1 stycznia 2019 r. wprowadzono do polskiego ustawodawstwa tzw. podatek od wyjścia (exit tax). Regulacja ta została przyjęta na grunt przepisów o podatkach dochodowych ${ }^{1}$ mocą Ustawy z dnia 23 października $2018 \mathrm{r}$.

Adiunkt w Katedrze Prawa Podatkowego, Wydział Prawa i Administracji, Uniwersytet Łódzki, doradca podatkowy, radca prawny, członek Stowarzyszenia Naukowego Prawa Podatkowego, e-mail: anowak@wpia.uni.lodz.pl

${ }^{1}$ Ustawa z dnia 26 lipca 1991 r. o podatku dochodowym od osób fizycznych (tekst jedn. Dz.U. z 2019 r., poz. 1387 ze zm.), dalej u.p.d.o.f.; ustawa z dnia 15 lutego 1992 r. 
o zmianie ustawy o podatku dochodowym od osób fizycznych, ustawy o podatku dochodowym od osób prawnych, ustawy - Ordynacja podatkowa oraz niektórych innych ustaw ${ }^{2}$. Zaadaptowanie tej konstrukcji do polskiego systemu prawnego związane było z obowiązkiem implementacji postanowień dyrektywy Rady (UE) 2016/1164 z dnia 12 lipca 2016 r. ustanawiającej przepisy mające na celu przeciwdziałanie praktykom unikania opodatkowania, które mają bezpośredni wpływ na funkcjonowanie rynku wewnętrznego ${ }^{3}$, w odniesieniu do art. 5 regulującego opodatkowanie niezrealizowanych zysków kapitałowych w przypadku przeniesienia aktywów, rezydencji podatkowej lub stałego zakładu.

Głównym celem powołanej dyrektywy, na co bezpośrednio wskazuje jej tytułu, jest chęć zapobiegania przypadkom unikania opodatkowania. Jak wynika z uzasadnienia do projektu ustawy nowelizującej, cel ten przyświecał też polskiemu ustawodawcy w związku z implementacją przepisów o podatku od wyjścia. W powołanym uzasadnieniu zwrócono uwagę na obowiązek takiego zaprojektowania regulacji nowelizującej u.p.d.o.f. i. u.p.d.o.p. w zakresie exit tax, by pozostawała w zgodzie z wytycznymi Trybunału Sprawiedliwości Unii Europejskiej (TSUE) dotyczącymi kształtu tego podatku. Należy przy tym zauważyć, że dyrektywa ATA przewiduje obowiązek objęcia podatkiem od wyjścia jedynie podatników podatku dochodowego od osób prawnych. Polski prawodawca poszedł jednak o krok dalej, rozszerzając zakres podmiotowy omawianej regulacji także na osoby fizyczne. Uzasadnieniem takiego rozwiązania jest, w opinii projektodawcy, powinność respektowania konstytucyjnej zasady równości.

Trzeba zauważyć, że po wejściu w życie przepisów o podatku od wyjścia pojawiły się w literaturze głosy krytykujące poszczególne elementy tej regulacji ${ }^{4}$. W szczególności dotyczyło to zasadności i kształtu opodatkowania tym podatkiem osób fizycznych. Zwracano bowiem uwagę na niezgodność wprowadzonych przepisów z prawem Unii Europejskiej (UE) i polską Konstytucją ${ }^{5}$, nadmierny fiskalizm, co w konsekwencji nie ma nic

o podatku dochodowym od osób prawnych (tekst jedn. Dz.U. z 2019 r., poz. 865), dalej: u.p.d.o.p.

2 Dz.U. z 2018 r., poz. 219, dalej: ustawa nowelizująca.

3 Dz.Urz. UE L 193 z dnia 21 lipca 2015 r., s. 1 ze zm., dalej: dyrektywa ATA.

${ }_{4}$ Zob. m.in. A. Nowak-Piechota, Podatek od wyjścia - analiza $i$ ocena regulacji, „Przegląd Podatkowy” 2019, nr 1, s. 34-40, a także mniejsze publikacje w dziennikach branżowych.

${ }^{5}$ Konstytucja Rzeczypospolitej Polskiej z dnia 2 kwietnia 1997 r. (Dz.U. z 1997 r., Nr 78, poz. 483 ze zm.), dalej: Konstytucja RP. 
wspólnego z zapewnieniem realizacji głównego celu przepisów, jakim jest zapobieganie unikaniu opodatkowania.

Wydaje się, że Minister Finansów dostrzegł ten problem, decydując się, po pół roku obowiązywania przepisów, na wydanie Rozporządzenia z dnia 27 czerwca 2019 r. w sprawie przedłużenia terminu do wpłaty przez podatników podatku dochodowego od osób fizycznych podatku należnego od dochodów z niezrealizowanych zysków ${ }^{6}$. Rozporządzenie to zmienia de facto model płatności podatku, co pośrednio ingeruje w podstawowe elementy konstrukcji tej daniny. Zabieg ten częściowo i doraźnie stwarza iluzję zgodności przepisów o podatku od wyjścia z prawem UE, a także Konstytucją RP. Trzeba bowiem brać pod uwagę, że to właśnie przyjęty model płatności exit tax, a przede wszystkim możliwość jej odroczenia (będąca swoistą ulgą w zapłacie podatku) pozwala na ocenę tej regulacji z punktu widzenia wytycznych TSUE oraz zasad i wartości konstytucyjnych.

\section{MODELE PŁATNOŚCI PODATKU OD WYJŚCIA}

W klasycznym ujęciu w przypadku opodatkowania osób fizycznych zdarzenie powodujące opodatkowanie w podatku od wyjścia związane jest ze zmianą rezydencji podatkowej (inaczej emigracją bądź wyjściem) ${ }^{7}$. Co do zasady obowiązek podatkowy ujawnia się w momencie poprzedzającym utratę statusu rezydenta przez podatnika w określonym państwie ${ }^{8}$. Jak podkreślono we wstępie, zasadnicze jest jednak określenie modelu płatności danego podatku. W tym kontekście wyróżniamy następujące sposoby płatności: natychmiastową (wówczas mamy do czynienia z immediate exit tax) oraz odroczoną (deferred exit tax).

System natychmiastowy charakteryzuje się tym, że podatek jest określany i płacony „w momencie wyjścia”, tzn. z uwzględnieniem odpowiedniego terminu na dokonanie zapłaty (np. 14-dniowego, z końcem miesiąca itd.).

${ }^{6}$ Dz.U. z 2019 r., poz. 1204, dalej: Rozporządzenie; wcześniej wydano także Rozporządzenie Ministra Finansów z dnia 31 stycznia 2019 r. w sprawie przedłużenia niektórych terminów w zakresie podatku od dochodów z niezrealizowanych zysków (Dz.U. z 2019 r., poz. 197), jednakże nie wprowadzało ono modyfikacji w modelu płatności podatku od wyjścia.

7 Bardziej złożona konstrukcja exit tax przewiduje także opodatkowanie w przypadku przeniesienia określonych składników majątku za granicę.

8 A. Nowak-Piechota, Podatek od wyjścia, Łódź 2018, s. 23-24. 
Niektórzy autorzy twierdzą, że tylko w takim przypadku mamy do czynienia z typowym podatkiem od wyjścia9. Z kolei model odroczenia poboru podatku stanowi $\mathrm{w}$ istocie ulgę $\mathrm{w}$ jego zapłacie i może przybrać postać bezpośrednią bądź pośrednią.

W pierwszym przypadku określenie omawianego podatku następuje w momencie wyjścia, podobnie jak w przypadku płatności natychmiastowej, $\mathrm{z}$ tą różnicą, że zapłata podatku jest przesunięta do momentu faktycznej realizacji zysków (rzeczywistego zbycia składników majątku) bądź wystąpienia innego zdarzenia (odroczenie bezpośrednie bezwzględne). Można także wprowadzić rozwiązanie przewidujące wstępne określenie kwoty zobowiązania w momencie emigracji, z brakiem obowiązku uiszczenia podatku, jeżeli składniki majątku nie zostaną zbyte (lub inne określone zdarzenie nie będzie miało miejsca) w określonym terminie, np. 10-letnim (odroczenie bezpośrednie względne). System odroczenia pośredniego zakłada natomiast, że podatek od wyjścia jest rozkładany na raty (podlegające zwykle uiszczeniu w odstępach rocznych) ${ }^{10}$.

Tego rodzaju ulga w zapłacie podatku, niezależnie od formy, jaką przybierze, może się wiązać $\mathrm{z}$ nałożeniem na podatnika dodatkowych obowiązków w celu zabezpieczenia w przyszłości poboru podatku, np. w postaci ustanowienia w państwie wyjścia przedstawiciela podatkowego, złożenia odpowiedniej gwarancji czy naliczania odsetek. Państwa uzależniają też utrzymywanie odroczenia płatności podatku od wywiązywania się z określonych obowiązków o charakterze informacyjnym w okresie poemigracyjnym.

Trzeba ponadto zauważyć, że w ramach systemów odroczenia występuje niekiedy możliwość zniesienia obowiązku zapłaty podatku od wyjścia w razie powrotu podatnika do państwa pierwotnej rezydencji (tzn. gdy następuje ponowne nabycie statusu rezydenta danego państwa), przy czym należy wówczas spełnić określone ustawowo warunki ${ }^{11}$.

${ }^{9}$ F. de Man, T. Albin, Contradicting Views of Exit Taxation Under OECD MC and TFUE: Are Exit Taxes Still Allowed in Europe?, „Intertax” 2011, nr 12, s. 615.

10 A. Nowak-Piechota, Podatek..., 2018, s. 28.

${ }^{11}$ L. de Broe, General Report, The Tax Treatment of Transfer of Residence by Individuals. IFA Cahiers de droit fiscal international, t. 87b, Rotterdam 2002, s. 39. 
Płatność podatku od wyjścia

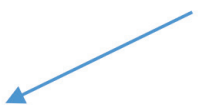

Natychmiastowa

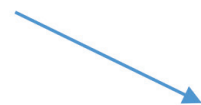

Odroczona

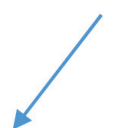

Bezpośrednio

Pośrednio

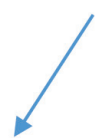

Względnie

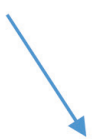

Bezwzględnie

Schemat 1. Modele płatności podatku od wyjścia Źródło: opracowanie własne.

Uwzględniając powyższe, nie może uciec z pola widzenia istota podatku od wyjścia, tj. przyjęcie fikcji, że podatnik w momencie emigracji zbywa składniki swojego majątku, w związku z czym zobowiązany jest do zapłaty podatku od tzw. niezrealizowanych zysków. Oznacza to więc, że wprowadzenie danego modelu płatności tego podatku może wpływać bezpośrednio na sytuację finansową podatników.

W przypadku płatności natychmiastowej dany podatnik może nie dysponować środkami pieniężnymi do zapłaty należnego podatku od wyjścia w związku z tym, że nie otrzymał on wynagrodzenia z tytułu zbycia opodatkowywanego składnika majątku. Następuje zatem naruszenie zasady zdolności płatniczej. Obowiązywanie podatku od wyjścia w takim kształcie skutkuje także nieuzasadnionym rozróżnieniem dwóch kategorii podatników - emigrujących i nieemigrujących, posiadających takie same składniki majątku. Podatnicy opuszczający państwo dotychczasowej rezydencji są postawieni w gorszej sytuacji względem podatników pozostających w kraju. Mają bowiem obowiązek zapłaty podatku od niezrealizowanych zysków, podczas gdy ci drudzy podatnicy uiszczą podatek dopiero wtedy, gdy dojdzie do rzeczywistego zbycia składników majątku. Prima facie można więc dostrzec sprzeczność takiego rozwiązania z konstytucyjną zasadą równości ${ }^{12}$. Poza tym natychmiastowy pobór podatku jest niedopuszczalny z punktu

12 A. Nowak-Piechota, Podatek..., 2018, s. 243. 
widzenia orzecznictwa TSUE ${ }^{13} \mathrm{w}$ przypadku emigracji do państw UE lub, szerzej, Europejskiego Obszaru Gospodarczego (EOG).

Uważa się, że model płatności odroczonej może „ratować” całą ideę podatku od wyjścia, czyniąc $z$ tej konstrukcji narzędzie $z$ jednej strony istotne $z$ perspektywy budżetu państwa (jako zapobiegające utracie wpływów budżetowych oraz unikaniu opodatkowania), a z drugiej pozostające w zgodzie z zasadami konstytucyjnymi (przede wszystkim zasadą równości) oraz prawem UE. Przyjmując bowiem rozwiązanie przewidujące odroczenie bezpośrednie podatku, zobowiązuje się podatników do jego zapłaty dopiero w momencie faktycznej realizacji zysków. Zapłata związana jest zatem z chwilą rzeczywistego zbycia składników majątku. Sytuacja takich podatników (emigrantów) zbliża się więc do sytuacji podatników, którzy pozostają w kraju i płacą podatek dopiero wówczas, gdy dojdzie do danej transakcji i uzyskają z tego tytułu dochód rzeczywisty (nie zaś hipotetyczny). Nie dochodzi także do naruszenia zasady zdolności płatniczej w związku z posiadaniem środków uzyskanych z tytułu wynagrodzenia ze zbycia danego składnika w celu uiszczenia podatku od wyjścia. Z drugiej strony w takim systemie państwo nie traci możliwości skutecznego dochodzenia należnego podatku od wyjścia w przyszłości, w związku z możliwością korzystania $\mathrm{z}$ rozwiązań przewidzianych w dyrektywach UE oraz nałożenia określonych obowiązków informacyjnych na emigrującego podatnika ${ }^{14}$. W razie emigracji poza UE państwo może uzależniać odroczenia podatku od złożenia odpowiedniego zabezpieczenia.

Powyżej opisaną rolę w mniejszym stopniu realizuje model odroczenia pośredniego. Z jednej strony rozłożenie na raty podatku jest środkiem łagodniejszym aniżeli obowiązek zapłaty natychmiastowej. $Z$ drugiej jednak w dalszym ciągu podatnik odczuwa negatywne skutki dla swojej płynności finansowej w związku z brakiem faktycznej realizacji zysków ${ }^{15}$. Dodatkowo można wciąż podnieść argument naruszenia zasady równości, porównując

13 Zob. np. wyrok TSUE z dnia 29 listopada 2011 r., National Grid Indus BV v. Inspecteur van de Belastingdienst Rijnmond/kantoor Rotterdam, C-371/10, C-301/11; wyrok TSUE z dnia 25 kwietnia 2013 r., Komisja v. Hiszpania, C-64/11; wyrok TSUE z dnia 18 lipca 2013 r., Komisja prz. Dania, C-261/11.

14 Por. wyrok TSUE z dnia 7 września 2006 r., $N$ v. Inspecteur van de Belastingdienst Oost/kantoor Almelo, C-470/04; wyrok TSUE z dnia 29 listopada 2011 r., National Grid Indus BV v. Inspecteur van de Belastingdienst Rijnmond/kantoor Rotterdam, C-371/10.

15 Wyrok TSUE z dnia 26 lutego 2019 r., Martin Wächtler prz. Finanzamt Konstanz, C-581/17. 
sytuację kategorii podatników emigrujących (płacących podatek w ratach) i nieemigrujących (którzy podatku nie płacą do momentu zbycia składników majątku). Poza tym TSUE dopuszcza odroczenie pośrednie podatku, ale tylko w przypadku opodatkowania podatkiem dochodowym od osób prawnych.

\section{ROZWIĄZANIE POLSKIE}

Zgodnie $\mathrm{z}$ art. 30da ust. 14 u.p.d.o.f. obliczony podatek od wyjścia podlega wpłacie do 7. dnia miesiąca następującego po miesiącu, w którym łączna wartość rynkowa przenoszonych składników majątku przekroczyła kwotę 4000000 zł (w tym terminie należy także złożyć deklarację podatkową). Przepis ten wdraża konstrukcję natychmiastowej płatności podatku od wyjścia.

Artykuł 30de ust. 1 u.p.d.o.f. w pewnych przypadkach przewiduje odroczenie płatności podatku na wniosek podatnika (rozłożenie podatku na raty na maksymalny okres pięciu lat). Dotyczy to jednak wyłącznie sytuacji, gdy przeniesienie składników majątku albo przeniesienie rezydencji podatkowej następuje na terytorium państwa członkowskiego UE lub innego państwa należącego do $\mathrm{EOG}^{16}$. Wprowadzone przepisy, podobnie jak dyrektywa ATA, przewidują, że w przypadku gdy istnieje realne ryzyko nieodzyskania podatku od dochodów z niezrealizowanych zysków, rozłożenie na raty zapłaty całości albo części tego podatku następuje po przedłożeniu przez podatnika zabezpieczenia wykonania zobowiązania podatkowego $\mathrm{z}$ tego tytułu wraz $\mathrm{z}$ opłatą prolongacyjną (art. 30de ust. 2 u.p.d.o.f.).

Analizując polskie przepisy u.p.d.o.f., można dojść do wniosku, że rodzimy ustawodawca przewidział kombinację modelu płatności natychmiastowej (która jest zasadą) i modelu odroczenia pośredniego podatku (na wniosek, w razie emigracji do UE lub innego państwa EOG). Na pierwszy rzut oka widać więc, że przepisy mogą podlegać zakwestionowaniu przez TSUE ${ }^{17}$. Pozostają także w sprzeczności z zasadami konstytucyjnymi, co powinno być przedmiotem badania Trybunału Konstytucyjnego.

${ }_{16}$ Mowa o państwie, które jest stroną - zawartej z RP lub Unią Europejską - umowy w sprawie wzajemnej pomocy przy odzyskiwaniu wierzytelności podatkowych, równoważnej wzajemnej pomocy przewidzianej w dyrektywie Rady 2010/24/UE z dnia 16 marca 2010 r. w sprawie wzajemnej pomocy przy odzyskiwaniu wierzytelności dotyczących podatków, ceł i innych obciążeń (Dz.Urz. UE L 84 z dnia 20 marca 2014 r., s. 1).

17 Krajowa Rada Doradców Podatkowych złożyła w tym zakresie stosowną skargę do TSUE (zob. https://kidp.pl/aktualnosciall.php/10/5916, dostęp: 10.08.2020). 
Niemniej jednak, jak zauważono na wstępie niniejszego artykułu, w połowie 2019 r. Minister Finansów wydał Rozporządzenie, w którym zmodyfikował przyjętą w ustawie konstrukcję dotyczącą modelu płatności podatku. Rozporządzenie to miało zapewne na celu złagodzenie ściśle fiskalnego charakteru podatku od wyjścia przez okres 3 lat od wejścia w życie tego uregulowania.

Zgodnie z $\$ 1$ ust. 1 tego Rozporządzenia przedłuża się termin do wpłaty przez podatników podatku dochodowego od osób fizycznych podatku należnego od dochodów z niezrealizowanych zysków, o którym mowa w art. 30da ust. 14 u.p.d.o.f. do:

1) 7. dnia miesiąca następującego po miesiącu, w którym podatnik utracił w całości lub w części składnik majątku będący przedmiotem opodatkowania tym podatkiem - w przypadku gdy utrata w całości lub w części tego składnika majątku nastąpiła przed dniem 1 grudnia 2021 r.;

2) dnia 31 grudnia 2021 r. - w pozostałych przypadkach.

$\mathrm{Z}$ przepisu tego wynika, że w polskim systemie obowiązuje obecnie model odroczenia bezpośredniego bezwzględnego - w odniesieniu do podatników, którzy zbyli lub zbędą składniki majątku przed 1 grudnia 2021. Pozostali podatnicy (tzn. ci, którzy nie zbędą składników majątku do 1 grudnia 2021 r.), mają zaś niekiedy możliwość późniejszej zapłaty podatku od wyjścia - tj. maksymalnie do 31 grudnia 2021 r. (czyli w dalszym ciągu mamy tutaj do czynienia z płatnością natychmiastową, lecz ze specyficznie wydłużonym terminem płatności w niektórych przypadkach).

Rozporządzenie, zapewne w sposób niezamierzony, znowu prowadzi więc do rozróżnienia dwóch kategorii podatników - w zależności od tego, kiedy nastąpiło rzeczywiste zbycie składników majątku. Jedni będą płacić podatek w momencie faktycznej realizacji zysków (a zatem będą dysponować środkami pieniężnymi na zapłatę podatku), inni natomiast zapłacą podatek być może w terminie późniejszym, aniżeli wynika z ustawy, lecz niezależnie od tego, czy dojdzie do rzeczywistego zbycia składników majątku. Przyjęcie takiej konstrukcji powoduje, że ponownie mamy do czynienia z przełamaniem zasady zdolności płatniczej, a co ciekawsze - z podwójnym naruszeniem zasady równości.

\section{Podsumowanie}

Zaprezentowane rozwiązania stanowią przykład nieudanego naprawiania błędów legislacyjnych aktami niższego rzędu - w tym przypadku Rozporządzeniem. Nie ulega bowiem wątpliwości, że przepisy podatku 
od wyjścia dotyczące osób fizycznych (abstrahując od rozwiązań w u.p.d.o.p.) nie mogą się ostać w obecnym kształcie i wymagają gruntownego przebudowania. Niemniej jednak w takim przypadku ustawodawca powinien był dokonać analizy obecnie obowiązujących przepisów, przy uwzględnieniu orzecznictwa TSUE, poglądów doktryny i praktyków prawa podatkowego oraz zmienić wadliwe przepisy u.p.d.o.f. Wydanie w tym zakresie Rozporządzenia było błędem z kilku powodów.

Po pierwsze, jak zauważono powyżej, przepisy tego aktu w sposób niezamierzony prowadzą do nieuzasadnionego rozróżnienia kolejnych kategorii podatników, co prowadzi do naruszenia zasady równości. Po drugie, taki zabieg nie dość, że jest nie do pogodzenia z zasadami przyzwoitej legislacji, to doprowadził też do niewątpliwego chaosu prawnego. Po trzecie (co wydaje się najistotniejsze), wydanie w tym przypadku Rozporządzenia narusza art. 217 Konstytucji RP. Przepis ten wprowadza ustawowy obowiązek regulacji podmiotu i przedmiotu opodatkowania, stawek podatkowych, a także zasad przyznawania ulg i umorzeń oraz kategorii podmiotów zwolnionych z podatków. Określanie modelu płatności podatku od wyjścia w przypadku wprowadzenia systemu odroczenia jest w istocie, jak podkreślono powyżej, ulgą w zapłacie podatku. W związku z tym kwestia ta objęta jest zakresem art. 217 Konstytucji RP, w ramach kategorii „zasady przyznawania ulg i umorzeń”. Nie można przy tym uznać, że w pojęciu „ulga” w rozumieniu powyższego przepisu nie mieści się ulga w zapłacie podatku od wyjścia. Wynika to $\mathrm{z}$ faktu, że mamy w tym przypadku do czynienia ze specyficznym elementem konstrukcji tego podatku, niestanowiącym instytucji ogólnego prawa podatkowego odnoszącej się do wszystkich podatków. Trzeba także brać pod uwagę, że ulgi podatkowe polegają na redukcji kwalitatywnych elementów podatku bądź kwoty samego podatku ${ }^{18}$. Odroczenie exit tax wpływa na moment zapłaty tego podatku, co, uwzględniając problematykę płynności finansowej podatników, przekłada się na jego ostateczną wysokość w ujęciu ekonomicznym ${ }^{19}$.

Konkludując, nie dość, że regulacja ustawowa dotycząca podatku od wyjścia zawiera liczne mankamenty, to Rozporządzenie wydane w celu częściowej ich naprawy stanowi przykład, by posłużyć się eufemizmem, legislacyjnej wpadki. W tym przypadku ustawa i modyfikujące

18 W. Nykiel, Ulgi i zwolnienia w konstrukcji prawnej podatku, Warszawa 2002, s. 14.

19 Związane jest to z obowiązkiem pomniejszenia określonych aktywów lub zwiększenia pasywów i ich ewentualnym oprocentowaniem. 
jej postanowienia Rozporządzenie są wadliwe, mamy zatem do czynienia z wtórną niekonstytucyjnością (pomijając już kwestie dotyczące zgodności z prawem UE).

\section{BIBLIOGRAFIA}

Broe de L., General Report, The Tax Treatment of Transfer of Residence by Individuals. IFA Cahiers de droit fiscal international, t. 87b, Rotterdam 2002.

Man de F., Albin T., Contradicting Views of Exit Taxation Under OECD MC and TFUE: Are Exit Taxes Still Allowed in Europe?, „Intertax” 2011, nr 12.

Nowak-Piechota A., Podatek od wyjścia, Łódź 2018.

Nowak-Piechota A., Podatek od wyjścia - analiza i ocena regulacji, „Przegląd Podatkowy” 2019, nr 1.

Nykiel W., Ulgi i zwolnienia w konstrukcji prawnej podatku, Warszawa 2002.

\section{"Worse is the ENEMy OF THE BAD", that IS, “FiXing” Legislative FAILURES ON THE EXAMPLE OF THE EXIT TAX REGULATION}

Summary. The aim of the article is to assess personal exit tax implemented into the Polish legal system in 2019, taking into account, particularly, the model of its payment. It is this element of the exit tax structure that is of key importance for establishing the compliance of the entire analysed regulation with the European Union law, as well as, constitutional principles and values. In this regard, the Resolution of the Ministry of Finance of June 27, 2019, which extends the deadline for the payment of exit tax in the case of natural persons, is an example of an exceptionally unsuccessful and legally flawed attempt to "fix" previous legislator's failures.

Keywords: exit tax, unrealized capital gains, tax credits, tax deferral 